\title{
Oncogene FGR
}

National Cancer Institute

\section{Source}

National Cancer Institute. Oncogene FGR. NCI Thesaurus. Code C18333.

Human Oncogene FGR is a mutated variant of FGR Gene (SRC Family), which encodes 529-aa 60-kDa p55-FGR, a protein tyrosine kinase that may bind PTPNS1 and contains 1 SH2 and 1 SH3 domain. Oncogene FGR disrupts normal cell function. 